\title{
Comparative Physico-chemical and Nutritional analysis of 1 year old and new Mudga [Vigna radiata (L.) R. Wilczek]
}

\author{
Research Article
}

\section{Saylee Deshmukh ${ }^{*}$, Vyas MK ${ }^{2}$, Shukla $\mathrm{VJ}^{3}$}

\author{
1. Ph.D.Scholar, 2. Professor and Head, Department of Basic Principles, \\ 3. Head, Pharmaceutical Chemistry Laboratory, \\ IPGTRA, Gujarat Ayurved University, Jamnagar, Gujarat, India
}

\begin{abstract}
In Ayurveda classics it is quoted that grains must be used between 1 - 2 years after its production while consumption of new grains should be avoided as its long term intake causes harmful effect on body as it is said to be Guru i.e. difficult to digest and Abhishyandi i.e. increases secretions of internal organs. It is said to be one of the cause for manifestation of Prameha which is being correlated with Diabetes mellitus on the basis of symptoms. Grains are major part of Indian diet. Present study aims at comparison between 1 year old and new Mudga [Vigna radiata (L.) R. Wilczek] on the basis of physico-chemical and nutritional analysis. Mudga has been selected as it is most commonly used and have great therapeutic efficacy.
\end{abstract}

Keywords: Mudga, Vigna radiata, Ahara

\section{Introduction}

The International Diabetes Federation (IDF) estimates the total number of diabetic subjects to be around 40.9 million in India and this is further set to rise to 69.9 million by the year 2025 (1). Analysis of the causes which are responsible for its manifestation are faulty diet and Lifestyle (2). Among them diet is an important part.

Grains are major part of Indian diet. It is major source of Carbohydrates and Proteins. In Ayurveda it is quoted that use of 1 year old grains is beneficial while consumption of new grains for long time leads to harmful effects on body (3). Old grains are considered between 1-2 years of its production while within one year of production it is considered as new (4). So, according to Ayurveda grains must be used after one year of its production.

In Ayurveda, new grains are quoted as guru i.e. not easily digestible and have more Kleda (liquid matrix) (5) which is described as cause for many diseases like Prameha which can be correlated with Diabetes mellitus on the basis of symptoms (6). Old grains are said to be Ruksha dry (3), Laghu (7) i.e. easily digestible (8). Therefore old grains are considered as wholesome for daily intake. Among variety of grains Mudga [Vigna radiata (L.) R. Wilczek] was selected for present study as it most common in Indian diet and its highly beneficial

*Corresponding Author:

\section{Saylee Deshmukh}

PhD scholar, Department of Basic Principles,

IPGT\&RA, Gujarat Ayurved University,

Jamnagar -361008.

E-mail: drsaylee@ymail.com effects and therapeutic efficacy described in Ayurveda classics. Loss on drying, Ash value and Fat contents were taken as parameters to assess Rukshsta while water soluble extracts was taken as parameter to assess Laghuta.

\section{Aims and Objective}

Comparison between 1 year old and new Mudga on the basis of physico-chemical and nutritional analysis.

\section{Materials and methods \\ Collection:}

Mudga [Vigna radiata (L.) R. Wilczek] was collected from periphery of Jamnagar (Gujarat) and stored in dry and hygienic condition for 1 year.

\section{Physico-chemical analysis:}

Following parameters were analyzed for different physico-chemical parameters by today's routine methods at the pharmaceutical chemistry lab, GAU, Jamnagar. Parameters were selected on the basis of common parameters mentioned for powder in Ayurvedic Pharmacopoeia of India and CCRAS guidelines (9).

\section{Physico-chemical Parameters (10):}

\section{Loss on Drying:}

The loss on drying of the samples was determined by taking $2 \mathrm{~g}$ accurately weighed sample in a watch glass, previously weighed and drying in an oven at $110^{\circ} \mathrm{C}$ till constant weight. The weight after drying was noted and the loss on drying was calculated. The percentage was calculated on the basis of air dried samples. 


\section{Ash Value:}

The ash value of the samples was determined according to IP'85. About $2.028 \mathrm{~g}$ of the drug was accurately weight and taken in a silica crucible incinerated in a muffle furnace at a temperature not exceeding $450^{\circ} \mathrm{C}$ for about 4 hours, cooled and weighed.

\section{Water Soluble extract:}

About $5 \mathrm{~g}$, accurately weighed, powder samples were taken in a conical flask. $100 \mathrm{ml}$ of distilled water was added to it, shaken well and kept overnight. Next day it was filtered. $20 \mathrm{ml}$ of the filtrate was taken in a previously weighed, dried porcelain evaporating dish and evaporated on a hot water bath. It was dried to constant weight in an oven and weighed. From the weight of the residue the water-soluble extractive percentage was calculated on the basis of air-dried sample.

\section{Alcohol Soluble extract:}

Methanol is having intermediate polarity. The methanol soluble extractive of the samples was determined in the similar way like water soluble extractive but by using methanol instead of water. The percentage of methanol soluble extractive was calculated.

\section{5. pH:}

Powder of 1 year old and new Mudga were dissolved in $50 \mathrm{ml}$ of water and $\mathrm{pH}$ was identified by separate litmus paper.

\section{High performance Thin Layer Chromatography study (HPTLC) (11):}

Methanol extract of 1 year old and new Mudga was spotted on pre coated silica gel GF 254 aluminium plate as $5 \mathrm{~mm}$ bands, $5 \mathrm{~mm}$ apart and $1 \mathrm{~cm}$ from the edge of the plates, by means of a Camag Linomate Vsample applicator fitted with a $100 \mu \mathrm{L}$ Hamilton syringe. Ethyl acetate: water: Acetic acid $(8: 1: 1)$ were used as the mobile phase. After development, Densitometric scanning was performed with a Camag TLC scanner III in reflectance absorbance mode at $254 \mathrm{~nm}$ and $366 \mathrm{~nm}$ under control of win CATS software. The slit dimensions were $6 \mathrm{~mm} \times 0.45 \mathrm{~mm}$ and the scanning speed was $20 \mathrm{~mm}$ per second. All HPTLC plates were scanned with filter fraction Savitsy-goloy 7, minimum slope 5, minimum height $10 \mathrm{AU}$, minimum area $50 \mathrm{AU}$, and maximum height $990 \mathrm{AU}$ with absorption unit.

\section{Nutritional analysis:}

Nutritional analysis of the two samples was performed at Radiant research laboratory, Bangalore.

\section{Estimation of energy value}

The sample calorific value was estimated (in Kcal) by multiplying the percentage crude protein, crude lipid and carbohydrate by the recommended factor used in analysis. The caloric value was determined based on the Atwater factor (12)

\section{Carbohydrate determination:}

$50 \mathrm{~mL}$ of alkaline cupric tartrate was added to TS into a $400-\mathrm{mL}$ beaker, along with $48 \mathrm{~mL}$ of water. It was mixed and pipet into a mixture of 5 grams of sample that had been diluted quantitatively with water to a $5.0 \%$ concentration. The solution was heated in a watch glass, regulating the heat so that boiling began after 4 minutes and continued boiling for another 2 minutes. The hot solution was filtered at once through a tared porcelain filtering crucible. The precipitate was washed with water maintained at $60^{\circ}$, then with $10 \mathrm{~mL}$ of alcohol. It was dried at $105^{\circ}$ to constant weight. A blank determination was performed and necessary corrections were performed. The corrected weight of the precipitate was compared with dextrose of known concentration (13).

\section{Estimation of crude fat:}

Fat is estimated as crude ether extract of dry material. The dry sample is weighed accurately into a thimble and plugged with cotton. The thimble is the placed in a Soxhlet apparatus and extracted with anhydrous ether for about $16 \mathrm{~h}$. The ether extract is filtered into a weighed conical flask. The flask containing the ether extract is washed 4 to 5 times with small quantity of ether and the washings are also transferred. The ether is then removed by evaporation and the flask with residue dries in an oven at $80-100{ }^{\circ} \mathrm{C}$, cooled in desiccators and weighed (14).

\section{Determination of crude protein:}

The crude protein was determined by the Kjeldahl method with slight modification. $0.5 \mathrm{~g}$ of the powder form of the sample was digested with $5 \mathrm{ml}$ of concentrated sulphuric acid in the presence of Kjeldahl catalyst. The nitrogen from the protein in the sample was converted to ammonium sulphate that reacted with $2.5 \mathrm{ml}$ of $2.5 \%$ Brucine reagent, $5 \mathrm{ml}$ of $98 \%$ sulphuric acid to give a coloured derivative and the absorbance read at $470 \mathrm{~nm}$. The percentage nitrogen was calculated and multiplied by 6.25 to obtain the value of the crude protein (15).

\section{Antioxidant DPPH analysis:}

The DPPH free radical is reduced to a corresponding hydrazine when it reacts with hydrogen donors. The DPPH radical is purple in color and upon reaction with hydrogen donor changes to yellow color. It is a discoloration assay, which is evaluated by the addition of the antioxidant to a DPPH solution in ethanol or methanol and the decrease in absorbance was measured at $490 \mathrm{~nm}$.

\section{Reagents:}

2, 2-Diphenyl 1-picryl hydrazyl solution (DPPH, $100 \mathrm{mM}$ ): $22 \mathrm{mg}$ of DPPH was accurately weighed and dissolved in $100 \mathrm{ml}$ of methanol. From this stock solution, $18 \mathrm{ml}$ was taken and diluted to 100 $\mathrm{ml}$ using methanol to obtain $100 \mathrm{mM}$ DPPH solution.

Preparation of test solutions:

$21 \mathrm{mg}$ each of the test substance was dissolved in distilled DMSO separately to obtain solutions of 21 $\mathrm{mg} / \mathrm{ml}$ concentrations. Each of these solutions was 
serially diluted separately to obtain lower concentrations.

Preparation of standard solutions: $10 \mathrm{mg}$ each of quercitin was weighed separately and dissolved in $0.95 \mathrm{ml}$ of Dimethyl sulfoxide (DMSO) to get 10.5 $\mathrm{mg} / \mathrm{ml}$ concentrations. These solutions were serially diluted with DMSO to get lower concentrations.

Procedure: The assay was carried out in a 96 well microtitre plate. To $200 \mathrm{ml}$ of DPPH solution, $10 \mathrm{ml}$ of each of the test sample or the standard solution was added separately in wells of the microtitre plate. The final concentration of the test and standard solutions used were $1000,500,250,125,62.5,31.25$ and 15.625, $7.812 \mathrm{mg} / \mathrm{ml}$. The plates were incubated at $37^{\circ} \mathrm{C}$ for 30 min and the absorbance of each solution was measured at $490 \mathrm{~nm}$, using a microplate reader.

\section{Observations and Results}

\section{Physico-chemical analysis:}

Physico-Chemical parameters are given in Table 1. Results of HPTLC study is shown in Table 2 . Densitogram of 1 year old and new Mudga is shown in Plates 1, 2, 3, 4.

\section{Nutritional analysis:}

Results of nutritional evaluation of 1 year old and new Mudga are given in Table 3.

\section{Discussion}

In the texts of Ayurveda, it is quoted that grains must be consumed after one year and within two years of their production. Properties of both have been mentioned separately. One year old grains are quoted as Ruksha dry (3), Laghu (7) i.e. easily digestible (8). While new grains are quoted as Guru (7) i.e. difficult to digest (8) and Abhishyandi i.e. increase the secretions of internal organs (7). The food articles which have Abhishyandi properties are said to increase Kleda (5) in body due to its more moisture contents which is quoted as cause for diseases like Prameha etc. (5).

Among the physico-chemical and nutritional parameters Loss on drying, Ash value and Fat contents were taken as parameters to assess Rukshsta while water soluble extracts was taken as parameter to assess Laghuta. In physico-chemical analysis, water soluble extract of 1 year old Mudga was more as compared to that of new Mudga. It shows that old Mudga has more bio-availability and easy digestibility than new Mudga because bio-availability of the drug depends on its water solubility (16). Loss on drying and Ash value was found more in new Mudga. It refers to the presence of more moisture contents in new Mudga as compared to old. $\mathrm{pH}$ value does not show major difference.

In nutritional analysis, Carbohydrates, Proteins and Energy content show almost similar value. Fat content of 1 year old Mudga is much low as compared to new Mudga. High fat diet have been proved to increase the risk of cardiovascular diseases (17). Therefore nowdays low-fat diets are being promoted for the prevention of heart disease. Antioxidant contents of 1 year old Mudga is higher than old Mudga which shows that intake of 1 year old Mudga is more beneficial for health.

\section{Conclusion}

In Ayurveda classics it is quoted that 1 year old grains are beneficial for health while new grains should be avoided due to its harmful effects on body. One year old grains are quoted as Ruksha (dry), Laghu i.e. easily digestible. While new grains are quoted as Guru i.e. difficult to digest and Abhishyandi i.e. increase the secretions of internal organs. In present study, loss on drying, Ash value and Fat contents were taken as parameters to assess Rukshsta while water soluble extracts was taken as parameter to assess Laghuta. Loss on drying and Ash value was found more in new Mudga. It refers to the presence of more moisture contents in new Mudga as compared to old. Water soluble extract of 1 year old Mudga was more as compared to that of new Mudga. It shows that old Mudga has more bio-availability and easy digestibility. It should be clinically correlated.

Table.1- Physico-chemical analysis of 1 year old and new Mudga

\begin{tabular}{|l|l|l|}
\hline Name of Test & Mudga New & Mudga Old \\
\hline Water soluble extract (\%) & 10.5 & 13.9 \\
\hline Loss on drying (\%) & 11.05 & 7.6 \\
\hline Ash value (\%) & 3.95 & 11.25 \\
\hline $\mathrm{pH}$ & 4.5 & 4 \\
\hline Alcohol soluble extracts & 6.2 & 5.96 \\
\hline
\end{tabular}


Saylee Deshmukh et.al., Physico-chemical and Nutritional difference between 1 year old and new Mudga

Table 2: showing consolidated data of HPTLC profile of 1 year old and new Mudga

Solvent System: Ethyl acetate : water : Acetic acid $(8: 1: 1)$

\begin{tabular}{|c|c|c|c|c|c|c|c|}
\hline Condition & \multicolumn{2}{|c|}{ No. of spots } & \multicolumn{2}{|c|}{ Max. Rf } & \multicolumn{3}{|c|}{ Area } \\
\hline \multirow[b]{2}{*}{$\begin{array}{l}\text { Short UV } \\
(254 \mathrm{~nm})\end{array}$} & $\begin{array}{c}\text { New } \\
\text { Mudga }\end{array}$ & $\begin{array}{c}\text { Old } \\
\text { Mudga }\end{array}$ & New Mudga & Old Mudga & $\overline{\mathrm{Nev}}$ & udga & Old Mudga \\
\hline & 5 & 6 & $\begin{array}{ll}0.01, & 0.56, \\
0.75, & 0.84, \\
0.93 & \end{array}$ & $\begin{array}{ll}0.05, & 0.19 \\
0.55, & 0.69 \\
0.83, & 0.93\end{array}$ & $\begin{array}{l}4058.3 \\
2081.0 \\
727.8\end{array}$ & $\begin{array}{l}1946.0, \\
1967.4,\end{array}$ & $\begin{array}{lr}493.9, & 292.7, \\
841.0, & 1645.5, \\
872.4, & \end{array}$ \\
\hline $\begin{array}{l}\text { Long UV } \\
(366 \mathrm{~nm})\end{array}$ & 5 & 1 & $\begin{array}{ll}0.01, & 0.56, \\
0.59, & 0.84, \\
0.93 & \end{array}$ & 0.59 & $\begin{array}{l}2942.4 \\
645.2 \\
298.9\end{array}$ & $\begin{array}{l}880.7, \\
454.7,\end{array}$ & 747.8 \\
\hline
\end{tabular}

Table.3- Nutritional analysis of 1 year old and new Mudga

\begin{tabular}{|l|l|l|}
\hline & Mudga New & Mudga Old \\
\hline Total Antioxidant & 683.95 & 922.98 \\
\hline Protein $(\mathrm{g} / 100 \mathrm{~g})$ & 24.48 & 25.45 \\
\hline Fat $(\mathrm{g} / 100 \mathrm{~g})$ & 0.97 & 0.38 \\
\hline Carbohydrate $(\mathrm{g} / 100 \mathrm{~g})$ & 62.04 & 63.09 \\
\hline Energy $(\mathrm{K} \mathrm{Cals} / 100 \mathrm{~g})$ & 354.81 & 357.58 \\
\hline
\end{tabular}

\section{References}

1) Sicree R, Shaw J, Zimmet P., Diabetes and impaired glucose tolerance: Diabetes Atlas; International Diabetes Federation, 3rd edition, Belgium: International Diabetes Federation; 2006, 15-103.

2) http://whqlibdoc.who.int/ publications/2011/9789241502283 eng.pdf

3) Agnivesh, Charaka Samhita with Ayurvedadipika commentary by Chakrapani, Reprint edition, Varanasi; Chaukhambha Surbharati Prakashan, Varansi; 2008. 171.

4) Vaagbhata, Ashtanga Hradayam with Ayurvedarasayana commentary by Hemadri. 9ed. Varanasi; Chaukhambha Orientalia; 2005. 89.

5) Agnivesh, Charaka Samhita with English translation by Dr. Ram Karan Sharma, Vd. Bhagwan Dash. Reprint edition, Chaukhambha Sanskrit Series Office, Varansi; 2005, 3, 299.

6) Sharma H, Chandola H M, Prameha in Ayurveda: correlation with obesity, metabolic syndrome and diabetes mellitus- etiology, classification and pathogenesis, Journal of Alternative and complementary medicine; Jun 17, 2011(6): 491-6

7) Sushruta, Sushruta Samhita with English translation by Kaviraj Kunjalal Bhishagratna, Dr. Jyotir Mitra, 3ed, Chaukhamba Sanskrit Sansthan, Varanasi, 2005, 1, 458.

8) Brahmashankar Shastri, Bhavaprakasha with Vidyotini Hindi commentary, 8ed, published by Chaukhamba Sanskrit Sansthana, Varanasi, Purvakhanda, 1993, 6/202, 188.

9) Anonymous, The Ayurvedic Pharmacopoeia of India, Part 1, Vol.1, New Delhi: Ministry of Health and Family Welfare, Department of AYUSH, Govt. of India, 2001

10) Anonymous 4, Govt. of India. The Ayurvedic Pharmacopoeia of India. 1st edition, part II, The Controller of publications, New Delhi;2006;Vol.II, Appendix -03:212.

11) Gurdeep R. Chatwal, Sham K. Anand, Industrial Method of Chemical analysis, 5ed. Himalaya publishing house, 2.272-2.503, 2.599-2.616, 2.6732.700 .

12) FAO Corporate Document Repository (2006 a). Calculation Of The Energy Content Of FoodsEnergy Conversion Factors. [http:/www.fao.org/ ag].

13) A.O.A.C., (1990). Association of Official Analytical Chemists. Official Methods of Analysis of the AOAC, 15th Edn., Washington, D.C. pp 375 -379 .

14) A.O.A.C., (1990). Association of Official Analytical Chemists. Official Methods of Analysis of the AOAC, 15th Edn., Washington, D.C.

15) A.O.A.C., (1990). Association of Official Analytical Chemists. Official Methods of Analysis of the AOAC, 15th Edn., Washington, D.C. pp 375 -379 .

16) Ketan T. Savjani, Anuradha K. Gajjar, Jignasa K. Savjani; Drug Solubility: Importance and Enhancement Techniques; ISRN Pharmaceutics, v.2012, Jul.5, 2012

17) Hooper, L; Abdelhamid, A; Moore, HJ; Douthwaite, W; Skeaff, CM; Summerbell, Effect of reducing total fat intake on body weight: systematic review and meta-analysis of randomised controlled trials and cohort studies, BMJ (Clinical research ed.), 2012, 345: e7666. 